\title{
Pengaruh Pengalaman Nasabah terhadap Loyalitas Nasabah Perbankan Kota Batam Melalui Saluran Transaksi Luring- Daring
}

\author{
Lady \\ Universitas Internasional Batam \\ lady@uib.ac.id \\ Metha Selvia \\ Universitas Internasional Batam \\ methaselvia18@gmail.com
}

\begin{abstract}
Indonesia sebagai Negara yang memiliki perkembangan pada bidang keuangan atau jasa perbankan menjadikan pertimbangan bagi peneliti untuk melakukan penelitian yang bermaksud meneliti lima dimensi yang ada pada pengalaman pelanggan nasabah perbankan terhadap loyalitas. Kelima dimensi tersebut mencakup cognitive dimension, affective dimension, sensory dimension, behavior dimension, dan juga social dimension. Pada dimensi affective, peneliti tidak hanya terpaku pada emosi positif namun juga negatif. Penelitian berfokus terhadap dua saluran interaksi yaitu saluran interaksi secara luring dan juga daring. Peneliti melakukan pendistribusian kuesioner menggunakan media berbasis daring yaitu google forms. Kuesioner memiliki 24 pertanyaan dan didistribusikan melalui media sosial, dengan jumlah kuesioner yang kembali sebanyak 309 responden. Penelitian ini terbatas dengan nasabah yang menggunakan atau memiliki rekening perbankan. Data yang berhasil dikumpulkan diuji memanfaatkan aplikasi SPSS untuk menguji data outer loading, kemudian dilanjutkan dengan menggunakan aplikasi SmartPLS untuk menguji hasil hipotesis. Hasil akhir penelitian menunjukkan bahwa emosi negatif lebih mempengaruhi nasabah dibandingkan emosi positif dalam keloyalitasannya terhadap perbankan. Selain itu, ditemukan juga bahwa perbedaan saluran interaksi yang digunakan nasabah mempengaruh pengalaman nasabah tersebut sehingga hal ini mempengaruhi loyalitas nasabah.
\end{abstract}

Kata Kunci pengalaman pelanggan, loyalitas pelanggan, dan dimensi perilaku

\section{PENDAHULUAN}

Saat ini penetrasi teknologi semakin luas dan cepat. Hampir seluruh sektor terdampak perkembangan teknologi ini, tidak terkecuali ekonomi. Teknologi membuat pola konsumsi, produksi dan distribusi berubah. Preferensi masyarakat beralih dari cara tradisional ke cara modern, yang dikenal dengan istilah luring dan daring. Sektor perbankan melakukan upaya keras agar tak terhalau gelombang modern yang mengubah total aktivitas nasabah perbankan. Perbankan berlomba-lomba memodernisasi system demi mempertahankan loyalitas nasabah (Rahma, 2020).

Kepuasan pada pengalaman nasabah selalu berjalan lurus dengan loyalitas pada nasabah. Loyalitas pada nasabah merupakan tujuan utama dalam pemasaran perusahaan terutama perusahaan perbankan. Bagi perusahaan perbankan yang terpenting adalah bagaimana proses dalam mencapai loyalitas nasabah ini. Hal yang dibutuhkan perusahaan adalah pengalaman positif yang dirasakan oleh nasabah. Dengan adanya pengalaman yang positif pada nasabah terhadap produk dan layanan yang perusahaan berikan, ini akan meningkatkan jumlah pada nasabah dan juga menghasilkan loyalitas pada nasabah.

Salah satu faktor yang mempengaruhi pengalaman nasabah dalam kepuasannya dalam perusahaan perbankan yaitu kualitas jasa yang diterima, pelayanan yang diberikan, keuntungan 
dari penggunaan layanan jasa tersebut, ketanggapan perusahaan dalam menerima keluhan nasabah serta faktor-faktor lainnya yang mendukung untuk kepuasan pengalaman nasabah. Strategi yang harus dilakukan oleh perusahaan perbankan adalah meningkatkan kualitas jasa dan pelayanan yang ada. Karena kualitas jasa yang diberikan ini mempengaruhi langsung kepuasan pengalaman dari nasabah. Dengan kualitas yang tinggi membuat nasabah ingin menjalin ikatan kuat dengan perusahaan dalam jangka panjang. Loyalitas nasabah yang didapat dari kepuasan pengalaman nasabah inilah yang menjadi kunci keberhasilan perusahaan.

Saat ini emosi pada pengalaman nasabah berperan sangat penting terhadap kepuasan nasabah yang mempengaruhi perusahaan di bidang jasa perbankan. Emosi ini yang ke depannya mempengaruhi keputusan pada nasabah, apakah nasabah akan melakukan penggunaan jasa secara berulang atau tidak. Seperti yang diketahui, menciptakan pengalaman kepuasan nasabah merupakan hal yang efektif untuk perusahaan perbankan di Indonesia dalam mencapai keunggulan kompetitif dan meningkatkan loyalitas dari nasabah.

Penelitian ini mengambil lima dimensi emosi sebagai acuan pengalaman nasabah, yaitu kognitif (cognitive), afektif (affective), sosial (social), perilaku (behavior), dan juga indera (sensory). Dalam pengalaman kepuasan nasabah, cognitive dimension berusaha mengarahkan nasabah untuk berpikir dan melibatkan kreativitas mereka dengan mengejutkan, membangkitkan minat dan memprovokasi mereka. Dengan kata lain, pengalaman harus memperkaya, meningkatkan pengajaran dan penemuan, dan mengasah keterampilan konsumen (Pine \& Gilmore, 2011). Dalam beberapa kasus, pengalaman kognitif bahkan dapat memberdayakan pelanggan untuk menyelesaikan masalah tertentu.

Affective dimension memunculkan kondisi mental disertai dengan proses fisik dan fisiologis yang dapat mengarah pada tindakan nyata nasabah untuk membayar lebih dan melakukan penggunaan produk atau jasa yang berulang (Brun, Rajaobelina, Ricard, \& Berthiaume, 2017). Emosi yang dialami nasabah ini yang perlu perusahaan jaga, dengan memastikan bahwa nasabah mendapatkan emosi positif yang menjadikan ini sebagai keuntungan perusahaan. Kemudian sensory dimension yang berhubungan dengan persepsi pengalaman melalui indra. Masing-masing dari lima indra, yaitu penglihatan, pendengaran, sentuhan, rasa dan juga penciuman. Aspek sensorik ini dapat dialami melalui berbagai titik kontak. Setelah itu ada behavior dimension yang mengandaikan bahwa pengalaman nasabah mempengaruhi nasabah secara fisik dengan memodifikasi tindakan yang diambil, kebiasaan dan gaya hidup. Terakhir social dimension yang berfokus pada interaksi nasabah, rasa memiliki (Nasermoadeli, Ling, \& Maghnati, 2013), sosialisasi dan keberlanjutan atau pengabadian hubungan antara perusahaan dan nasabah.

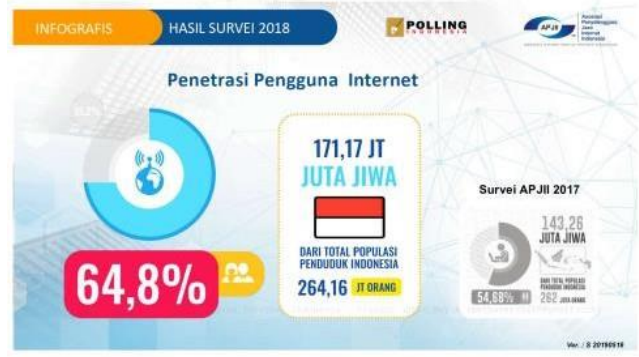

\section{Gambar 1 Penetrasi Pengguna Internet. Sumber: Asosiasi Penyelenggara Jasa Internet Indonesia (2019).}

Berdasarkan hasil survei yang diperoleh dari (Asosiasi Penyelenggara Jasa Internet Indonesia, 2019), dapat dilihat bahwa perkembangan Indonesia terhadap penggunaan internet sangat tinggi dan meningkat dari tahun sebelumnya. Perkembangan dalam penggunaan internet yang semakin canggih ini membuat perusahaan jasa perbankan berlomba-lomba melakukan penerapan teknologi pada layanannya. Berbagai macam inovasi yang dilakukan perbankan dalam mengimbangi kemajuan teknologi internet yaitu dengan menciptakan produk teknologi, seperti mobile banking, internet banking, sms banking, dan juga electronic data capture untuk transaksi 
jual beli menggunakan kartu kredit ataupun kartu debit.

Perkembangan teknologi internet ini juga menunjukkan bahwa titik kontak perusahaan perbankan dengan nasabah saat ini tidak hanya bergantungan kepada interaksi luring. Namun interaksi berbasis daring juga menjadi titik kontak interaksi bagi perusahaan perbankan dan nasabah. Dengan adanya dua titik kontak interaksi yang berbeda ini maka terjadi perbedaan untuk respon pengalaman nasabah terhadap pelayanan yang diberikan oleh perusahaan jasa perbankan. Hal ini menjadikan pengalaman pada nasabah menjadi lebih kompleks. Sebagai contoh untuk berbasis web, nasabah dihadapkan dengan berbagai faktor seperti ketersediaan informasi yang lebih luas, aksesibilitas 24 jam setiap hari dan dimana saja tanpa adanya keterbatasan dan kehadiran fisik manusia. Oleh karena itu dibutuhkannya penelitian yang menunjukkan pengalaman nasabah dalam dua saluran ini (Klaus \& Maklan, 2013; Lemon \& Verhoef, 2016) dan menyelidiki dampak apa saja yang dipengaruhi dari perbedaan dua saluran ini. Jika terdapat perbedaan maka perusahaan jasa perbankan perlu menyesuaikan strategi untuk kemajuan perusahaannya.

\section{LANDASAN TEORI}

Penelitian terdahulu yang dilaksanakan oleh Brun et al., (2017) mengenai pengaruh lima dimensi yaitu cognitive dimension, affective negative dimension, affective positive dimension, sensory dimension, behavioral dimension, dan social dimension. Song, Bae, dan Han, (2019) melaksanakan penelitian yang bertujuan untuk mengidentifikasi hubungan struktural antara lovemarks (mystery, sensuality, intimacy, trust, reputation dan performance), lovemarks (brand love dan brand respect) dan loyalty dari kedai kopi. Bustamante dan Rubio (2017) melaksanakan penelitian, di mana penelitian ini memiliki tujuan mengusulkan dan memvalidasi skala untuk mengukur in-store customer experience (ISCX) dengan mengalami respon cognitive, affective, social, dan physical. Hasil penelitian ini memberikan bukti bahwa skala urutan ketiga formatif dengan dimensi urutan kedua reflektif (customer exprience) dan tiga dimensi urutan pertama reflektif (cognitive, affective, dan physical experience) memiliki sifat psikometrik yang memuaskan. Penelitian ini juga memberikan informasi yang berguna tentang pengaruh skala ISCX pada variabel kinerja utama seperti satisfaction dan loyalty terhadap toko.

Wang et al., (2017) melaksanakan penelitian yang mengembangkan model konseptual dimana intensitas tampilan dan keaslian tampilan secara berbeda mempengaruhi customer loyalty dengan mengubah affective reaction dan cognitive appraisals. Ou dan Verhoef, (2017) meneliti hubungan antara customer equity drivers (CEDs) dengan loyalty. Penelitian ini bertujuan untuk menguji efek dari positive dan negative emotions pada loyalty intentions dan untuk menentukan apakah emosi ini memoderasi hubungan positif antara CED dan loyalty intentions.

Kruger (2016) melaksanakan penelitian dengan tujuan menentukan satu penjelasan bagaimana self-brand connection dikaitkan dengan loyalty melalui brand experience. Temuan analisis mengkonfirmasi bahwa brand experience sepenuhnya memediasi hubungan antara selfbrand connection dan loyalty. Brand experience secara kolektif dipandang sebagai termasuk dimensi sensory, affective, behavioral, dan intellectual yang bersama-sama mencerminkan tingkat keseluruhan brand experience.

Srivastava dan Kaul (2016) melaksanakan penelitian untuk mempelajari dampak dari customer experience pada attitudinal dan behavioral loyalty. Bilgihan (2016) melaksanakan penelitian dengan menggunakan hedonic dan utilitarian sebagai karakteristik dari situs web yang memberikan pengalaman positif dan mempengaruhi loyalty serta mempengaruhi brand equity dan trust. Imran Khan Zillur Rahman (2016) melaksanakan penelitian dengan tujuan untuk menguji pengaruh $e$-tail brand experience terhadap $e$-brand trust dan $e$-brand loyalty. Penelitian ini juga menguji apakah gender juga memoderasi pengaruh ini.

Foroudi et al., (2016) melaksanakan penelitian dengan menggunakan teori kompleksitas untuk memahami pengaruh innovation capability dan customer experience terhadap reputation dan loyalty. Artikel ini mengakui pengalaman affective dan intellectual sebagai elemen kunci dari customer experience dan mengusulkan kerangka kerja konseptual dengan proposisi penelitian. 
Ding dan Tseng, (2015) melaksanakan penelitian yang bertujuan lebih jauh memeriksa mekanisme mediasi untuk menjelaskan pengaruh brand experience terhadap brand loyalty dengan mengintegrasikan pandangan pengalaman tentang konsumsi dan teori emosi penilaian. Brand awareness/associations, perceived quality dan hedonic emotions memediasi hubungan antara brand experience dan brand loyalty. Emosi hedonis memainkan peran mediasi yang kuat. Selain itu, itu adalah pandangan pengalaman konsumsi daripada teori penilaian emosi yang memainkan peran dominan dalam akuntansi untuk pengaruh pengalaman merek pada loyalitas merek.

Lada, et al., (2014) melaksanakan penelitian dengan tujuan untuk menguji peran dimensi brand experience (yaitu sensory, affective, behavioral, dan intellectual). Jani dan Han (2014) melaksanakan penelitian dengan menilai personality, satisfaction, loyalty, ambience, dan image di lingkungan hotel. Dengan menggunakan openness, conscientiousness, extraversion, agreeableness, dan juga neuroticism sebagai personality factors yang mempengaruhi satisfaction. Maheshwari, Lodorfos, dan Jacobsen (2014) melaksanakan penelitian untuk menyelidiki hubungan antara brand experience, brand commitment (yang terdiri dari affective dan continuance commitment) dan brand loyalty sejauh menyangkut sektor otomotif. Namun continuance commitment ditemukan tidak memiliki dampak yang berarti pada loyalty konsumen terhadap suatu merek, diperkirakan bahwa faktor seperti harga dan preferensi lain yang tersedia tidak memberi efek dorongan untuk menjaga hubungan tersebut.

Lin dan Bennett, (2014) melaksanakan uji konstruksi customer experience dan hubungannya dengan satisfaction dan loyalty; serta menguji apakah program loyalty memberikan efek moderasi pada hubungan tersebut. Ali et al., (2014) melaksanakan penelitian dengan tujuan untuk menguji pengaruh empat aspek customer experience pada memories dan loyalty.

Bruwer et al., (2013) meneliti dengan tujuan ntuk berkontribusi pada basis pengetahuan pariwisata anggur mengenai dampak experience mencicipi kamar anggur pada customer loyalty. Kim dan Choi (2013) menguji model teoritis dari hubungan antara service outcome quality, interaction quality, peer-to- peer quality, dan customer experience quality, dan pengaruh dari customer experience quality terhadap customer loyalty. Selain itu, temuan menunjukkan adanya efek moderasi oleh gender.

Narteh et al., (2013) melaksanakan penelitian yang menunjukan bahwa keenam kunci dari relationship marketing (competence, commitment, conflict handling, trust, communication, dan relational bonds) memiliki pengaruh yang sangat signifikan dan kuat terhadap customer loyalty. Cetin dan Dincer (2014) melaksanakan penelitian lapangan kuantitatif untuk menentukan dan menunjukkan dampak social interactions pada customer loyalty dan physical environment dalam organisasi perhotelan.

Deng, Yeh, dan Sung (2013) melaksanakan penelitian dengan memberikan dukungan empiris pada gagasan ikatan antara service quality, consumption emotions, perceived value, customer satisfaction, customer complaints, dan customer loyalty. Nysveen et al., (2013) melaksanakan penelitian dengan tujuan menguji skala brand loyalty yang baru diterbitkan dalam konteks merek layanan. Selain memvalidasi dimensi yang ditetapkan dari skala pengukuran (sensory, intellectual, affective dan behavioral), studi ini menguji dimensi tambahan yaitu relational experience yang diusulkan sebagai sangat relevan untuk merek layanan.

Lee dan Chang, (2012) melaksanakan penelitian, di mana penelitian ini menggunakan variabel dari experience of experiential marketing, activity involvement, satisfaction dan loyalty intentions. Sampel dari penelitian ini adalah wisatawan penikmat anggur di Taiwan. Hasil analisis menjelaskan bahwa pengalaman, keterlibatan aktivitas dan kepuasan secara signifikan mempengaruhi niat loyalitas wisatawan anggur. Kepuasan memainkan peran mediasi dalam model perilaku. Studi ini memberikan wawasan lebih lanjut tentang pemodelan perilaku pariwisata anggur.

Lim et al., (2011) meneliti dampak customer experience pada loyalty melalui tinjauan komprehensif literatur yang ada pada konsep pengalaman pelanggan dan literatur merek layanan. Selain itu, penelitian ini untuk menyelidiki anteseden dan konsekuensi dari pengalaman 
pelanggan dengan perhatian khusus pada loyalitas. Walsh et al., (2011) mengintegrasikan penelitian yang berkaitan dengan store-related cognitions, customer emotions (arousal dan pleasure), satisfaction dan loyalty ke dalam satu kerangka kerja. Zhou dan Lu (2011) menguji penelitian dengan hasil bahwa network externalities dan flow experience secara signifikan mempengaruhi percieved usefulness dan satisfaction, lebih lanjut menentukan user loyalty.

Gracia et al., (2011) melaksanakan penelitian dengan menilai positive affective terhadap customer loyalty dengan menjadikan service quality sebagai mediasinya. Ismail (2011) meneliti hubungan antara perceived service quality pada customer experience terhadap loyalty. Iglesias et al., (2011) melaksanakan penelitian dengan tujuan untuk mempelajari hubungan langsung dan tidak langsung antara brand experience dengan brand loyalty. Christodoulides dan Michaelidou (2011) melaksanakan penelitian dengan tujuan untuk menyelidik efek motif $e$-satisfaction pada $e$-loyalty dan perilaku social interaction menjadi motif yang berhubungan langsung dengan $e$ loyalty.

Chen dan $\mathrm{Hu}$ (2010) melaksanakan penelitian bahwa relational benefits berdampak secara langsung dan tidak langsung terhadap perceived value dan customer loyalty. Pollack (2009) melaksanakan penelitian dengan tujuan untuk menilai kembali hierarchical service quality model (HSQM) yang terdiri dari tiga dimensi yaitu interaction quality, physical environment quality, dan outcome quality. Selain itu penelitian ini meneliti lebih lanjut ikatan antara service quality yang diukur dengan satisfaction dan customer loyalty.

Chang dan Chen (2008) melaksanakan penelitian mengenai pengaruh bagaimana customer interface quality, satisfaction, dan juga switching cost terhadap e-loyalty. Penelitian ini juga berpendapat bahwa hubungan antar konstruk ini dimoderasi dengan pengalaman internet. Chen et al., (2008) meneliti hubungan lima elemen VEM (sense, interaction, pleasure, flow, community relationship) pada customer browse dan purchase intentions serta loyalty, dan efek moderasi dari economic orientation dan convenience shopping orientation and Internet experience pada hubungan VEM dan customer intetions.

Plank dan Newell (2007) meneliti dampak konflik sosial yang dirasakan pada hubungan pembeli-penjual yang ada. Hasilnya menunjukkan bahwa ketika tingkat konflik sosial meningkat, persepsi tentang loyalitas hubungan menurun. Auh et al., (2007) menyelidiki hubungan antara coproduction dengan customer loyalty dengan mempertimbangkan hubungan customer expertise, customer-advisor communication, customer affective commitment, dan interactional justice bersama tingkat co-production.

Lee et al., (2007) melaksanakan penelitian yang membahas proses konsumen menjadi loyal terhadap merek layanan ritel dengan menunjukkan bahwa pengaturan merek layanan ritel, brand satisfaction, brand trust dan commitment adalah pendorong loyalty; brand trust dan continuance commitment sangat penting.

\section{Loyalty}

Menurut Brun et al., (2017) loyalty sering dikaitkan dengan sikap yang menguntungkan dan perilaku berulang. Loyalty ini dapat memangkas biaya, meningkatkan promosi dari mulut ke mulut dan meningkatkan pendapatan pembelian bagi perusahaan. Menurut Chen dan $\mathrm{Hu}$ (2010) customer loyalty merupakan kunci variabel yang berkaitan dengan probabilitas pelanggan akan kembali, membuat rujukan bisnis, memberikan kata-kata yang kuat, serta memberikan rujukan dan propaganda. Sedangkan menurut Chang dan Chen 2008 loyalty didefiniskan sebagai perilaku pembelian berulang yang ditunjukkan selama periode yang berkelanjutan dan didorong dengan sikap yang menguntungkan terhadap perusahaan. Loyalty dianggap sebagai konstruksi konatif dan tindakan dalam kerangka konseptual.

\section{Pengaruh Cognitive Dimension terhadap Loyalty}

Menurut Brun et al., (2017) pengalaman cognitive dapat memberdayakan pelanggan untuk menyelesaikan masalah tertentu dan kesadaran yang dicapai oleh pengalaman cognitive berdampak pada waktu yang dihabiskan di toko dan pembelian yang dilaksanakan. Pengalaman 
yang beragam dan interaktif berdampak positif terhadap evaluasi pelanggan terhadap suatu merek melalui pengalaman cognitive yang lebih intens dan menyimpulkan bahwa dalam konteks virtual, pengalaman mengalir menghasilkan berbagai konsekuensi positif termasuk hasil cognitive, terkait tugas, dan perilaku (Bilgihan, 2016).

\section{Pengaruh Affective Dimension terhadap Loyalty}

Menurut Brun et al., (2017) respon emosional pelanggan juga dipertimbangkan dalam menilai pengalaman pelanggan. Dimensi affective memunculkan kondisi mental disertai dengan proses fisik dan fisiologis yang dapat mengarah pada tindakan nyata. Dimensi affective ini dipecah menjadi dua, yaitu positif dan negatif. Emosi positif dari konsumen adalah cara yang baik untuk meningkatkan dari mulut ke mulut, menarik konsumen untuk membayar lebih dan meningkatkan bisnis yang berulang sedang emosi negatif mempengaruhi penurunan loyalitas konsumen.

Pengalaman emosional positif berulang yang dialami pada pelanggan pada akhirnya akan berkontribusi terhadap kepuasan pelanggan yang mendasari keputusan pelanggan untuk setia pada suatu organisasi ataupun perusahaan (Auh et al., 2007). Pengalaman emosional negatif kerap dirasakan pelanggan dengan menggunakan neuroticism yang merupakan sebagai penilaian pengalaman pelanggan yang negatif (Jani dan Han, 2014). Emosi pelanggan melibatkan dua hal secara luas tipe yang dipelajari dalam literatur perilaku konsumen: integral dan insidental emosi dengan menggabungkan valensi positif dan negatif dari emosi integral sebagai pendorong loyalty (Ou dan Verhoef, 2017).

\section{Pengaruh Sensory Dimension terhadap Loyalty}

Menurut Brun et al., (2017) pengalaman dapat mengubah lingkungan dan menjadikannya lebih menyenangkan bagi konsumen. Aspek sensory dapat dialami melalui berbagai titik kontak seperti iklan, web, dan tempat penjualan. Sensory atau elemen emosional dari pengalaman total memiliki yang lebih besar berdampak pada membentuk preferensi konsumen daripada atribut produk atau layanan (Chen et al., 2008).

\section{Pengaruh Behavior Dimension terhadap Loyalty}

Brun et al., (2017) berpendapat bahwa dimensi behavior pengalaman pelanggan harus berusaha menunjukkan perilaku yang terkait dengan tindakan konsumsi. Menurut hierarchical service quality model (HSQM) pada penelitian Pollack (2009) bahwa kualitas interaksi adalah attitude, behavior dan expertise. Kualitas ini yang mempengaruhi loyalty. Dimensi behavior terkait dengan tindakan motorik dan pengalaman perilaku yang diciptakan oleh stimulasi terkait merek berdasarkan desain dan identitas produk, pengemasan, komunikasi, dan lingkungan (Lada, et al., 2014) berpendapat dimensi. Sedangkan Iglesias et al., (2011) berpendapat respons behavior yang ditonjolkan oleh rangsangan perihal merek yang merupakan bagian dari pengalaman yang mempengaruhi loyalty.

\section{Pengaruh Social Dimension terhadap Loyalty}

Menurut Brun et al., (2017), pengalaman pelanggan saat ini lebih bersifat social daripada sebelumnya, mengingat berbagai saluran, media, dan titik sentuh yang dinikmati pelanggan dengan perusahaan dan keragaman interaksi yang terlibat. Dengan dimensi social ini dapat dipercaya adanya kelanjutan hubungan antara perusahaan dan konsumen.

Interaksi social dan proses individu sebagai bagian dari pengalaman pelanggan, pelanggan merupakan kontributor aktif untuk realitas social sehingga loyalty didasarkan pada kualitas dan intensitas hubungan yang muncul antara individu dan orang lain yang berinteraksi dalam lingkungan sosial (Bustamante dan Rubio, 2017).

\section{Pengaruh Moderating Effect}

Brun et al., (2017) berpendapat bahwa pengaruh dari pengalaman pelanggan terhadap 
Jurnal Ekonomi \& Ekonomi Syariah Vol 4 No 2, Juni 2021

E-ISSN : 2599-3410 | P-ISSN : 2614-3259

DOI : https://doi.org/10.36778/jesya.v4i2.484

loyalitas dapat bervariasi sesuai dengan saluran yang digunakan. Dibandingkan dengan pengaturan cabang / agensi tempat karyawan dan pelanggan lain hadir, konteks berbasis daring berarti bahwa konsumen sendirian di depan layar komputernya melaksanakan pengekplorasian. Mengingat juga bahwa ada beberapa dimensi yang dianggap lebih efektif dan mudah diakses apabila melaksanakan layanan tatap muka serta sebagian dimensi juga memiliki hal yang positif jika kegiatan pelayanan dirasakan melalui sistem berbasis daring.

\section{METODE PENELITIAN}

Penelitian ditujukan untuk mengetahui interaksi sebab serta akibat antar variabel independen dengan variabel dependen berdasarkan data yang dikumpulkan sehingga dapat disimpulkan bahwa metode yang digunakan yaitu metode kasual komparatif (Causal-Comparative Research). Penelitian ini memiliki objek yakni untuk memahami dampak dari pengalaman nasabah dan dimensi pada loyalitas nasabah di sektor perbankan, serta untuk memastikan apakah ada perbedaan pengalaman yang dirasakan berdasarkan saluran interaksi yang digunakan (luring maupun daring). Populasi yang dimiliki penelitian ini yaitu masyarakat Kota Batam yang memiliki rekening tabungan dan pernah menggunakan jasa pelayanan dari perbankan baik itu secara luring maupun daring. Sedangkan untuk sampel dari penelitian ini adalah nasabah dari Bank BRI, Bank Mandiri, Bank BCA, Bank BNI, Bank BTN, serta Bank CIMB Niaga, dan lainnya.

Penelitian ini memiliki 24 butir pertanyaan dengan jumlah minimum responden yaitu 240 . Teknik yang digunakan untuk pengutipan sampel pada penilitian ini adalah teknik Non Probability Sampling dengan metode sampling accidental, dimana pada teknik ini siapa saja yang secara tidak terencana atau bertepatan berpapasan dengan peneliti serta dinilai memenuhi kriteria yang dibutuhkan dapat digunakan sebagai sampel.

Penelitian ini memanfaatkan data primer yang didistribusikan peneliti secara acak menggunakan media platform daring yaitu google forms. Kuesioner ini didistribusikan melalui media sosial daring seperti Line, Facebook, Twitter, Instagram, WhatsApp dan lain sebagainya. Selain itu, peneliti memanfaatkan data sekunder untuk menunjang penelitian ini seperti data yang berdasarkan artikel, jurnal, buku, dan lain sebagainya. Peneliti memanfaatkan persamaan structural (PLS-SEM) untuk meneliti hubungan antar variabel, baik itu dengan adanya indikator terhadap konstuk maupun hubungan yang dimiliki antar konstruk (Santoso, 2014).

\section{HASIL PENELITIAN}

Hubungan antara variabel dinyatakan bersifat signifikan apabila $P$-values menyandang nilai kurang dari 0,05 atau $T$-statistics yang menyandang nilai lebih dari 1,96 (Hair et al., 2011). Tabel 1 menjelaskan hasil dari uji signifikansi antara variabel cognitive dimension, affective negative dimension, affective positive dimension, sensory dimension, behavior dimension, dan social dimension.

Tabel 1 Hasil Uji Signifikasi Pengaruh Langsung

\begin{tabular}{|c|c|c|c|}
\hline $\mathbf{X} \rightarrow \mathbf{Y} /$ Direct & $\begin{array}{c}\boldsymbol{P} \\
\text { Values }\end{array}$ & $\begin{array}{c}\boldsymbol{T} \\
\text { Statistics }\end{array}$ & Kesimpulan \\
\hline Cognitive Dimension $\rightarrow$ Loyalty & 0,000 & 7,830 & H1: Berpengaruh Signifikan \\
\hline $\begin{array}{c}\text { Affective Negative Dimension } \rightarrow \\
\text { Loyalty }\end{array}$ & 0,000 & 3,714 & H2: Berpengaruh Signifikan \\
\hline $\begin{array}{c}\text { Affective Positive Dimension } \rightarrow \\
\text { Loyalty }\end{array}$ & 0,088 & 1,710 & $\begin{array}{c}\text { H3: Berpengaruh Tidak } \\
\text { Signifikan }\end{array}$ \\
\hline $\begin{array}{c}\text { Sensory Dimension } \rightarrow \text { Loyalty } \\
\text { Behavior Dimension } \rightarrow \text { Loyalty }\end{array}$ & 0,437 & 0,777 & $\begin{array}{c}\text { H4: Berpang Tidak } \\
\text { Signifikan }\end{array}$ \\
\hline Social Dimension $\rightarrow$ Loyalty & 0,808 & 0,243 & H6: Berpengaruh Tidak \\
\hline
\end{tabular}


DOI : https://doi.org/10.36778/jesya.v4i2.484

\begin{tabular}{|l|l|l|l|}
\hline \hline & & & Signifikan \\
\hline
\end{tabular}

Catatan: $p$-values $<0,05, t$-statistics 1,96

Tabel 2 Hasil Uji Signifikasi Pengaruh Langsung Efek Moderasi

\begin{tabular}{|c|c|c|c|}
\hline $\mathrm{X} \rightarrow \mathrm{Y} /$ Direct & $\begin{array}{c}P \\
\text { Values }\end{array}$ & \begin{tabular}{|c|}
$T$ \\
Statistics
\end{tabular} & Kesimpulan \\
\hline $\begin{array}{l}\text { Cognitive Dimension (Moderating) } \rightarrow \\
\text { Loyalty }\end{array}$ & 0,000 & 3,996 & Berpengaruh Signifikan \\
\hline $\begin{array}{l}\text { Affective Negative Dimension } \\
\text { (Moderating) } \\
\rightarrow \text { Loyalty }\end{array}$ & 0,551 & 0,597 & Berpengaruh Tidak Signifikan \\
\hline $\begin{array}{l}\text { Affective Positive Dimension (Moderating) } \\
\rightarrow \text { Loyalty }\end{array}$ & 0,000 & 4,343 & Berpengaruh Signifikan \\
\hline Sensory Dimension Moderating $\rightarrow$ Loyalty & 0,513 & 0,655 & Berpengaruh Tidak Signifikan \\
\hline $\begin{array}{l}\text { Behavior Dimension (Moderating) } \rightarrow \\
\text { Loyalty }\end{array}$ & 0,000 & 3,540 & Berpengaruh Signifikan \\
\hline $\begin{array}{l}\text { Social Dimension (Moderating) } \rightarrow \\
\text { Loyalty }\end{array}$ & 0,036 & 2,105 & Berpengaruh Signifikan \\
\hline
\end{tabular}

Catatan: $p$-values $<0,05, t$-statistics 1,96

Cognitive dimension merupakan dimensi yang memiliki dampak terbesar pada loyalty. Hasil menunjukkan bahwa fakta yang menyebabkan konsumen mempelajari sesuatu dan tetap memperhatikan sekitar mereka dapat meningkatkan loyalitas pelanggan di sekitar (Brun et al., 2017). Begitu pula penelitian yang dilakukan (Cho \& Fiore, 2015) bahwa kognitif dari pelanggan berkontribusi besar baik itu dalam rasa ataupun pola pikir terhadap produk.

Affective negative dimension menunjukkan hubungan negatif yang signifikan dengan emosi pelanggan negatif tidak kondusif untuk membangun loyalty pelanggan (Brun et al., 2017). Affective positive dimension menunjukkan bahwa emosi positif tidak memberikan dampak yang signifikan terhadap loyalty. Pelanggan tidak terlalu suka terkejut atau terperangkap, dan mengalami emosi positif seperti kejutan, hiburan, pesona memiliki tingkat yang sangat kecil dalam kasus-kasus yang diteliti (Brun et al., 2017). Pengalaman emosional negatif kerap dirasakan pelanggan (Jani dan Han, 2014).

Sensory dimension berkaitan dengan lima indera, namun hal ini tidak memberikan dampak yang signifikan terhadap loyalty. Bahwasanya dalam pelayanan secara langsung pengalaman pelanggan secara sensorik dinilai kurang merangsang atau kaku, bahkan untuk beberapa sektor di tingkat service escape dapat menjelaskan bahwa tidak ada sensory dimension (Brun et al., 2017). Elemen sensory berkontribusi pada pembentukan sikap positif yang penting untuk menelusuri dan niat membeli (Chen et al., 2008).

Behavior dimension berdampak signifikan terhadap loyalty. Dalam hal ini tidak seirama dengan penelitian sebelumnya (Brun et al., 2017) yang berpendapat bahwa aspek perilaku dari pengalaman pelanggan sulit untuk dipahami di sektor perbankan dan hampir tidak terbukti seperti reaksi penonton yang mudah diamati. Sedangkan Pollack (2009) berpendapat bahwa pendorong utama untuk kualitas jasa yang menimbulkan loyalitas untuk pelanggan adalah sikap dan perilaku.

Dampak yang tidak signifikan dihasilkan variabel social dimension terhadap loyalty. Hal ini menunjukkan yang berbeda dengan penelitian yang dilakukan sebelumnya (Brun et al., 2017), dimana penelitian ini memahami bahwa layanan yang sopan dan sikap positif dari karyawan garis depan sangat penting. Penting bagi perusahaan dalam memberikan pengalaman kepada pelanggan mereka melalui berbagai saluran untuk komersialisasi pasokan dan interaksi sosial (Bustamante \& Rubio, 2017). 
Tabel 3 Hasil Uji $R$ Square

\begin{tabular}{|c|c|c|}
\hline Variabel & $R$ Square adjusted & Persentase \\
\hline Loyalty & 0,467 & 46,7 \\
\hline
\end{tabular}

Hasil Uji $R$ Square pada variabel loyalty sebesar 0,467 (46,7\%) diterangkan melalui variabel cognitive dimension, affective negative dimension, affective positive dimension, sensory dimension, behavior dimension, social dimension, dan moderating effect sedangkan selisih sebesar 53,5\% diterangkan melalui variabel yang tidak terdapat pada penelitian ini. Goodness of fit pada inner model memanfaatkan $R$-square variabel laten dependen dan memanfaatkan kaitan prediktif untuk outer model (Ghozali \& Latan, 2015). GoF digunakan untuk menakar seberapa baik nilai pengamatan yang dihasilkan oleh model. Nilai model membuktikan lebih dari 0,36 yang membuktikan bahwa model tersebut menyandang kemampuan model prediksi yang baik.

\section{KESIMPULAN}

Berdasarkan dari hasil penelitian, dibuktikan bahwa keseluruhan variabel independen yang digunakan dalam penelitian ini dapat mempengaruhi dengan kuat loyalitas pelanggan perbankan di Kota Batam. Variabel-variabel yang mempengaruhi loyalitas pelanggan perbankan secara signifikan adalah cognitive dimension, affective negative dimension, dan behavior dimension. Industri perbankan direkomendasikan memperhatikan ketiga dimensi ini lebih jauh, seperti cognitive dimension dengan menggunakan media yang lebih interaktif dengan pelanggan.

\section{Daftar Pustaka}

Ali, F., Hussain, K., \& Ragavan, N. A. (2014). Memorable Customer Experience: Examining the Effects of Customers Experience on Memories and Loyalty in Malaysian Resort Hotels. Procedia - Social and Behavioral Sciences, 144, 273-279. https://doi.org/10.1016/j.sbspro.2014.0 7.296

Asosiasi Penyelenggara Jasa Internet Indonesia. (2019). Hasil Survei Penetrasi dan Profil Perilaku Pengguna Internet Indonesia Tahun 2018. Asosiasi Penyelenggara Jasa Internet Indonesia, 51. Retrieved from https://apjii.or.id/survei2018

Auh, S., Bell, S. J., McLeod, C. S., \& Shih. (2007). Co-production and customer loyalty in financial services. Journal of Retailing, 83(3), 359-370. https://doi.org/10.1016/j.jretai.2007.03.001

Bilgihan, A. (2016). Gen y customer loyalty in online shopping: An integrated model of trust, user experience and branding. Computers in Human Behavior, $\quad 61, \quad 103-113$. https://doi.org/10.1016/j.chb.2016.03.0 14

Brun, I., Rajaobelina, L., Ricard, L., \& Berthiaume, B. (2017). Impact of customer experience on loyalty: a multichannel examination. Service Industries Journal, 37(5-6), 317-340. https://doi.org/10.1080/02642069.201 7.1322959

Bruwer, J., Coode, M., Saliba, A., \& Herbst. (2013). Wine tourism experience effects of the tasting room on consumer brand loyalty. Tourism Analysis, 18(4), 399-414. https://doi.org/10.3727/108354213X13 736372325957

Bustamante, J. C., \& Rubio, N. (2017). Measuring customer experience in physical retail environments. Journal of Service Management, 28(5), 884-913. https://doi.org/10.1108/JOSM-06-2016-0142

Cetin, G., \& Dincer, F. I. (2014). Influence of customer experience on loyalty and word-of-mout in hospitality operations. Anatolia, 25(2), 181-194. https://doi.org/10.1080/13032917.2013.841094 
Chang, H. H., \& Chen, S. W. (2008). The impact of customer interface quality, satisfaction and switching costs on e- loyalty: Internet experience as a moderator. Computers in Human Behavior, 24(6), 2927-2944. https://doi.org/10.1016/j.chb.2008.04.014

Chen, J., Luo, M. M., Ching, R. K. H., \& Liu, C. C. (2008). Virtual experiential marketing on online customer intentions and loyalty. Proceedings of the Annual Hawaii International Conference on System Sciences, 271. https://doi.org/10.1109/HICSS.2008.495

Chen, P. T., \& Hu, H. H. (2010). The effect of relational benefits on perceived value in relation to customer loyalty: An empirical study in the Australian coffee outlets industry. International Journal of Hospitality Management, 29(3), 405-412. https://doi.org/10.1016/j.ijhm.2009.09.006

Cho, E., \& Fiore, A. M. (2015). Conceptualization of a holistic brand image measure for fashionrelated brands, Journal of Consumer Marketing, 32(4), 255 265. https://doi.org/10.1108/JCM-07-2014-1063

Christodoulides, G., \& Michaelidou, N. (2011). Shopping motives as antecedents of e-satisfaction and e- loyalty. Journal of Marketing Management, 27(1-2), 181-197. https://doi.org/10.1080/0267257X.201 0.489815

Deng, W. J., Yeh, M. L., \& Sung, M. L. (2013). A customer satisfaction index model for international tourist hotels: Integrating consumption emotions into the American customer satisfaction index. International Journal of Hospitality Management, 35, 133-140. https://doi.org/10.1016/j.ijhm.2013.05. 010

Diamantopoulos, A., Sarstedt, M., Fuchs, C., Wilczynski, P., \& Kaiser, S. (2012). Guidelines for choosing between multi-item and single-item scales for construct measurement: A predictive validity perspective. Journal of the Academy of Marketing Science, 40(3), 434449. https://doi.org/10.1007/s11747-011-0300-3

Ding, C. G., \& Tseng, T. H. (2015). On the relationships among brand experience, hedonic emotions, and brand equity. European Journal of Marketing, 49(7-8), 994-1015. https://doi.org/10.1108/EJM-04-2013-0200

Foroudi, P., Jin, Z., Gupta, S., Melewar, T. C., \& Foroudi, M. M. (2016). Influence of innovation capability and customer experience on reputation and loyalty. Journal of Business Research, 69(11),4882-4889. https://doi.org/10.1016/j.jbusres.2016. 04.047

Ghozali, I., \& Latan, H. (2015). Partial Least Squares: Konsep, Teknik dan Aplikasi Menggunakan Program SmartPLS 3.0, -2/E. Semarang: Badan Penerbit Undip.

Gracia, E., Bakker, A. B., \& Grau, R. M. (2011). Positive emotions: The connection between customer quality evaluations and loyalty. Cornell Hospitality Quarterly, 52(4), 458-465. https://doi.org/10.1177/1938965510395379

Iglesias, O., Singh, J. J., \& Batista-Foguet, J. M. (2011). The role of brand experience and affective commitment in determining brand loyalty. Journal of Brand Management, 18(8), 570-582. https://doi.org/10.1057/bm.2010.58

Imran Khan Zillur Rahman. (2016). E-tail brand experience's influence on e- brand trust and ebrand loyalty. Journal of Service Management, 44(6), 588-606. https://doi.org/10.1108/MBE-09-2016- 0047

Ismail, A. R. (2011). Experience marketing: An empirical investigation. Journal of Relationship Marketing, 10(3), 167-201. https://doi.org/10.1080/15332667.201 1.599703

Jani, D., \& Han, H. (2014). Personality, satisfaction, image, ambience, and loyalty: Testing their relationships in the hotel industry. International Journal of Hospitality Management, 37, 
11-20. https://doi.org/10.1016/j.ijhm.2013.10. 007

Kim, H., \& Choi, B. (2013). The Influence of Customer Experience Quality on Customers' Behavioral Intentions. Services Marketing Quarterly, 34(4), 322-338. https://doi.org/10.1080/15332969.2013.827068

Klaus, P., \& Maklan, S. (2013). Towards a better measure of customer experience. International Journal of Market Research, 55(2), 227-246. https://doi.org/10.2501/IJMR-2013- 021

Kruger, L.-M. (2016). Brand loyalty: Exploring self-brand connection and brand experience. Journal of Product \& Brand Management. https://doi.org/10.1108/EL-01-2017- 0019

Lee, K., Huang, H., \& Hsu, Y. (2007). Trust, Satisfaction and Commitment- On Loyalty to International Retail Service Brands. Asia Pacific Management Review , 12(3), 161-169.

Lee, T. H., \& Chang, Y. S. (2012). The influence of experiential marketing and activity involvement on the loyalty intentions of wine tourists in Taiwan. Leisure Studies, 31(1), 103-121. https://doi.org/10.1080/02614367.201 1.568067

Lemon, K. N., \& Verhoef, P. C. (2016). Understanding customer experience throughout the customer journey. Journal of Marketing, 80(6), 69-96. https://doi.org/10.1509/jm.15.0420

Lim, L., Woodside, A., \& College, B. (2011). Literature review and research directions Delivered by Ingenta to : Guest User Delivered by Ingenta to : Guest User. 11(3), 205-225.

Lin, Z., \& Bennett, D. (2014). Examining retail customer experience and the moderation effect of loyalty programmes. International Journal of Retail and Distribution Management, 42(10), 929-947. https://doi.org/10.1108/IJRDM-11- 2013-0208

Maheshwari, V., Lodorfos, G., \& Jacobsen, S. (2014). Determinants of Brand Loyalty: A Study of the Experience- Commitment-Loyalty Constructs. International Journal of Business Administration, 5(6), 13-23. https://doi.org/10.5430/ijba.v5n6p13

Narteh, B., Agbemabiese, G. C., Kodua, P., \& Braimah, M. (2013). Relationship marketing and customer loyalty: Evidence from the ghanaian luxury hotel industry. Journal of Hospitality Marketing and Management, 22(4), 407-436. https://doi.org/10.1080/19368623.201 2.660564

Nasermoadeli, A., Ling, K. C., \& Maghnati, F. (2013). Evaluating the Impacts of Customer Experience on Purchase Intention. International Journal of Business and Management, 8(6). https://doi.org/10.5539/ijbm.v8n6p128

Nysveen, H., Pedersen, P. E., \& Skard, S. (2013). Brand experiences in service organizations: Exploring the individual effects of brand experience dimensions. Journal of Brand Management, 20(5), 404-423. https://doi.org/10.1057/bm.2012.31

Ou, Y. C., \& Verhoef, P. C. (2017). The impact of positive and negative emotions on loyalty intentions and their interactions with customer equity drivers. Journal of Business Research, 80(July), 106-115. https://doi.org/10.1016/j.jbusres.2017. 07.011

Pine, B. J. I., \& Gilmore, J. H. (2011). The Experience Economy, Updated Edition. Harvard Business Review Press.

Plank, R. E., \& Newell, S. J. (2007). The effect of social conflict on relationship loyalty in business markets. Industrial Marketing Management, 36(1), 59-67. https://doi.org/10.1016/j.indmarman.2 005.03.012

Pollack, B. L. (2009). Linking the hierarchical service quality model to customer satisfaction and loyalty. Journal of Services Marketing, 23(1), 42-50. https://doi.org/10.1108/08876040910933084 


\section{JESYA}

JURNAL EKONOMI \& EKONOMI SYARIAH

Jurnal Ekonomi \& Ekonomi Syariah Vol 4 No 2, Juni 2021

E-ISSN : 2599-3410 | P-ISSN : 2614-3259

DOI : https://doi.org/10.36778/jesya.v4i2.484

Lada, S., Suki, N. M., \& Sidin, S. M., (2014). The Roles of Brand Experience in Forming Loyalty Intention. Labuan e-Journal of Muamalat and Society, 8, 39-49.

Rahma, A. (2020). Era Perkembangan Teknologi, Bagaimana Nasib Bank-bank Kecil? Liputan 6. Retrieved February, 19, 2020 from https://www.liputan6.com/bisnis/read/4168626/eraperkembangan-teknologi-bagaimana-nasib-bank-bank-kecil

Santoso, S. (2014). Statistik Multivariat Edisi Revisi. Jakarta: Elex Media Komputindo.

Song, H. J., Bae, S. Y., \& Han, H. (2019). Emotional comprehension of a name- brand coffee shop: focus on lovemarks theory. International Journal of Contemporary Hospitality Management, 31(3), 1046-1065. https://doi.org/10.1108/IJCHM-07- 2017-0436

Srivastava, M., \& Kaul, D. (2016). Exploring the link between customer experience-loyaltyconsumer spend. Journal of Retailing and Consumer Services, 31, 277-286. https://doi.org/10.1016/j.jretconser.201 6.04.009

Walsh, G., Shiu, E., Hassan, L. M., Michaelidou, N., \& Beatty, S. E. (2011). Emotions, storeenvironmental cues, store-choice criteria, and marketing outcomes. Journal of Business Research, 64(7), 737-744. https://doi.org/10.1016/j.jbusres.2010. 07.008

Wang, Z., Singh, S. N., Jessica Li, Y., Mishra, S., Ambrose, M., \& Biernat, M. (2017). Effects of employees' positive affective displays on customer loyalty intentions: An emotionsassocial-information perspective. Academy of Management Journal, 60(1), 109-129. https://doi.org/10.5465/amj.2014.0367

Zhou, T., \& Lu, Y. (2011). Examining mobile instant messaging user loyalty from the perspectives of network externalities and flow experience. Computers in Human Behavior, 27(2), 883-889. https://doi.org/10.1016/j.chb.2010.11.0 13 